\title{
PATHOLOGY OF COMPLETE ATRIOVENTRICULAR BLOCK IN CHRONIC CHAGAS' MYOCARDITIS
}

\section{Zilton A. Andrade, Sonia G. Andrade, Moysés Sadigursky and Edmundo J. N.Câmara}

\begin{abstract}
Sclero-atrophy, fibrosis, vascular ectasia, phlebosclerosis and mild non-specific chronic inflammatory changes were observed in variable location and proportion involving the atrioventricular conducting tissue of the heart in five human cases of chronic Chagas' myocarditis associated with complete atrioventricular block. One case presented complete destruction of the $A-V$ conduction system. In three cases the lesions were disseminated all along the conducting tissue but did not cause anywhere a complete disruption in the continuity of the system. The distal portion of the bundle branches were the most damaged sector of the system, except for the fasciculi of the posterior division of the left bundle branch which were relatively preserved. One case exhibited bilateral sclero-atrophy of the bundle branches as the main change; and another showed early and mild fibrocalcific damage of the penetrating portion of the His bundle. The $A$-V node appeared as the least involved part of the conducting system in the cases studied.

Demonstration of the lesions in this series of cases seems important because: a) it reveals that complete atrioventriculr block in chronic Chagas' disease results from disseminated lesions and not from focal disruptive change as has been commonly observed in cases of other etiologies; $b$ ) it shows that chronic inflammation can produce at the end variable and widespread vascular, degenerative and fibrotic alterations within the conducting tissue of the heart, which may lead to its total destruction.
\end{abstract}

Key words: Chronic Chagas' myocarditis. Atrioventricular block.

The occurrence of complete atrioventricular block (A-V block) in chronic Chagas' myocarditis has called the attention of investigators since the earliest Chagas' descriptions ${ }^{34}$. It is not a rare manifestation, since Ginefra et al ${ }^{8}$ were able to collect and study 103 cases, but its true prevalence is difficult to evaluate. There is a surprisingly variable percentage of cases of complete atrioventricular block associafed with Chagas' disease presented by different groups, and this probably reflects different criteria of patient selection ${ }^{9}$. However, actual pathological data are scanty 213 and practically there is no information concerning clinical and pathological correlations.

In general complete and permanent $\mathrm{A}-\mathrm{V}$ block is the electrocardiographic alteration that can be better correlated with morphological findings at the atrioventricular conduction system. In such cases an interruptive lesion can almost always be demonstrated in the cardiac conducting system 5 . The nature, extension and localization of such lesion are of fundamental importance for the understanding of cardiac physiopathology, especially when the application of new and advanced methods for the diagnosis and treatment of

Gonçalo Moniz Research Center (FIOCRUZ) and the Department of Internal Medicine, Federal University of Bahia. Salvador, Bahia, BRAZIL

Recebido para publicação em $7 / 3 / 88$ cardiac arrhythmias are contemplated, such as for electrophysiological exploration and cardiac pacing.

The present paper represents a clinico-pathological study of five patients presenting with complete A$\mathrm{V}$ block and dying of congestive cardiac failure due to chronic Chagas' myocarditis. This series of cases is a rather small one, but display the advantage of these being cases confirmed at necropsy and having the conducting system of the heart submitted to complete serial sectioning, which allowed all its lesions to be mapped, for adequate electrocardiographic correlations.

\section{MATERIAL AND METHODS}

General data on the 5 patients included in this study are presented in Table 1. Clinical diagnosis of Chagas' disease was based on well known clinical and epidemiological data ${ }^{16}$ and also included the demonstration of antibodies against Trypanosoma cruzi in the sera of all five patients. These same cases have been briefly mentioned in previous publications 12 .

All necropsies were complete. The heart was fixed in totum in $10 \%$ neutral formalin for at least 4 days. Soon before that, its chambers had been injected with the fixative until the organ assumed its usual shape. For the study of the atrioventricular conducting system, a block of tissue was removed from the upper 
Andrade $Z A$, Andrade SG, Sadigursky $M$, Cámara EJN. Pathology of complete atrioventricular blocí in chronic Chagas' myocarditis. Revista da Sociedade Brasileira de Medicina Tropical 21: 7-13, Jan-Mar, 1988

Table 1 - General clinical data on 5 patients with chronic Chagas' heart disease and complete A-V block

\begin{tabular}{|c|c|c|c|c|c|}
\hline Case & $\begin{array}{c}\text { Age } \\
\text { (years) }\end{array}$ & Sex & Duration* & Stokes-Adams & Observations \\
\hline 1 & 74 & $\mathbf{M}$ & 3 years & No & $\begin{array}{l}\text { Episodes of ventricular tachycardia, palpita- } \\
\text { tions without loss of conscience }\end{array}$ \\
\hline 2 & 32 & $\mathbf{M}$ & 14 years & Yes & Faints, no convulsions. \\
\hline 3 & 46 & $\mathbf{M}$ & 4 years & Yes & $\begin{array}{l}\text { 10.17.69: compl. LBBB } \\
\text { 06.12.70: } 2 \text { nd. degree A-V block ( } 2: 1 \text { type) } \\
\text { 06.10.72: compl. A-V block No changes in } \\
\text { QRS } \\
\text { 03.10.73: Idem, plus atrial flutter and multi- } \\
\text { focal premature beats }\end{array}$ \\
\hline 4 & 66 & F & Indeter.** & Yes & Frequent palpitations \\
\hline 5 & 41 & $\mathbf{F}$ & 10 months & No & - \\
\hline
\end{tabular}

* Duration of disease was entımated trom the tirst cardiac complaints referred to by the patients.

** Indeterminated: psychiatric patient.

All patients had arterial blood pressure levels within normal limits, except patient No 1 in whom pressure of $180 / 110$ was registered.

part of the interventricular septum, together with a small portion of the lower part of the interatrial septum. This block was limited anteriorly by the coronary ostium and posteriorly by the end of the membranous septum and measured $3 \mathrm{~cm}$ in height and $2 \mathrm{~cm}$ in width. It was divided into two, embedded in paraffin and completely sectioned at 5 micrometer. An average of 4 to 5 thousands serial sections were mounted in continous and transparent plastic tapes, according to the method of Pickett and Sommer ${ }^{14}$. The sections thus prepared were submitted to the Masson's trichrome staining method and examined microscopically by means of a special device adapted at the basis of an ordinary research microscope, which allowed the quick screening of the sections and the subsequent mapping of the lesions present. When necessary, a piece of the plastic with a section was cut out off the tape and prepared for conventional microscopical examination. Some selected paraffin sections were mounted directly on glass slides and stained with hematoxylin and eosin, or Mallory's phosphotungstic hematoxylin, or by the Weigert-Van Gieson technique.

\section{RESULTS}

Data related to atrial and ventricular rates, as well as the duration and morphological patterns of
QRS, are shown on Table 2. The QRS pattern of complete right bundle branch block (CRBBB) was predominant, appearing in four of the patients, while only one showed a pattern of left bundle branch block (LBBB). The predominant type was seen associated with left anterior hemiblock (LAH) in three patients, while another presented deviation of the QRS axis to the left $\left(-150^{\circ}\right)$.

Thickness of the interventricular septum was at least $30 \%$ less than normal, as usually happen in cases of progressive cardiac failure due to chronic Chagas' myocarditis.

A combination of pictures showing the distribution of the lesions along the conduction tissue, the main histological change and electrocardiographic tracings concerning each case appear in Figure 1 to 5.

Histological changes were represented by atrophy fibrosis, chronic inflammation, vascular ectasia, phlebosclerosis and fatty infiltration. Case No 4 presented total destruction of the conduction system, from the atrioventricular node to the most distal portions of the peripheral bundle branches examined.

Replacing the specific tissues, it was found a loose connective tissue, with some islet of fatty tissue, dilated and congested thin-walled blood vessels and a few scattered collections of mononuclear inflammatory cells. 
Andrade ZA, Andrade SG, Sadigursky M, Cámara EJN. Pathology of complete atrioventricular block in chronic Chagas' myocarditis. Revista da Sociedade Brasileira de Medicina Tropical 21: 7-13, Jan-Mar, 1988

Table 2 - Electrocardiographic findings in 5 patients with chronic Chagas' heart disease and complete atrioventricular block

\begin{tabular}{ccccl} 
Case & $\begin{array}{c}\text { Atrial rate } \\
(\text { bpm) }\end{array}$ & $\begin{array}{c}\text { Ventricular } \\
\text { rate }(\text { bpm })\end{array}$ & $\begin{array}{c}\text { Duration } \\
\text { QRS (sec) }\end{array}$ & \multicolumn{1}{c}{ QRS Pattern } \\
\hline 1 & 74 & 38 & 0.16 & RBBB + LAH \\
2 & 68 & 36 & 0.16 & RBBB + SQRS $-150^{\circ}$ \\
3 & 86 & 45 & 0.16 & RBBB + LAH \\
4 & 79 & 43 & 0.16 & RBBB + LAH \\
5 & 94 & 42 & 0.15 & RBBB + LAH
\end{tabular}

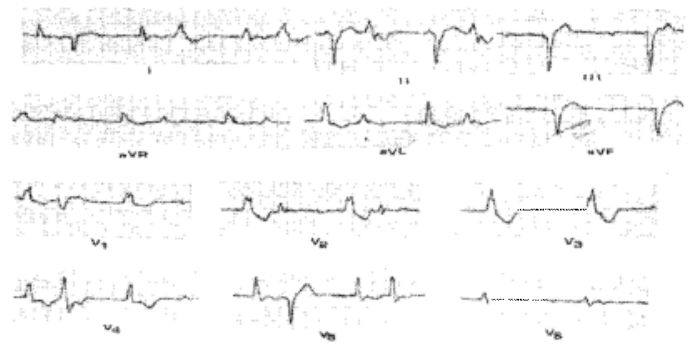

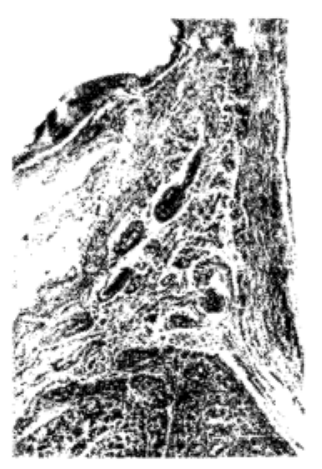

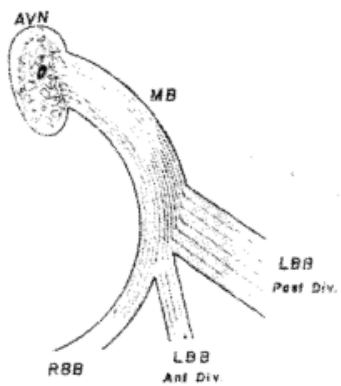

Figure 1 - Case n.o 1, 74 year old male. Microphotography displays the lower part of the His bundle. There is dense band of fibrosis at the left side of the bundle and vascular congestion and dilatation plus atrophy of specific fibers in the remaining conducting tissue. Masson's trichrome, $80 \mathrm{X}$. Distribution of the lesions shows the anterior portion of the left bundle branch as being little involved.

Case No 3 disclosed a relatively good preservation of the conduction system structures from the atrioventricular node down to the origin of the bundle branches. At this point an advanced process of sclero-atrophy involved the distal portions of both bundle branches. Sclero-atrophy means the disappearance of the specific fibers with persistence of the fibrous stroma. At the AV-node, the main artery disclosed a conside-

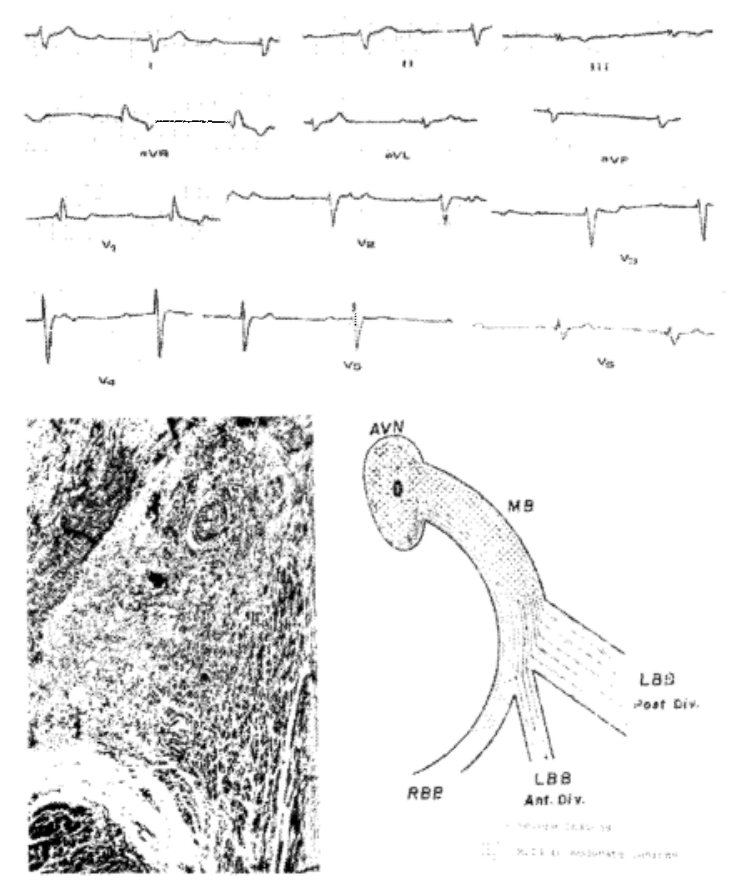

Figure 2-Case n.o 2, 32 year old male. Severe and diffuse involvement of the entire conducting system, with only the $A-V$ node and the left part of the His bundle with mild to moderate lesions. The microscopic picture shows advanced fibrosis and anomalous vessels occupying the right $2 / 3$ of the His bundle, while some relatively preserved conducting fibers appear at the left side. Masson's trichrome, $80 \mathrm{X}$.

rable degree of thickening of its wall with reduction of its lumen.

Except for the cases above mentioned, the three others showed similar and variegated pictures, which can be described as follows:

Atrioventricular node: the presence of mild to moderate and diffuse atrophy with subsequent stromal condensation was the dominant feature. At the inferior 

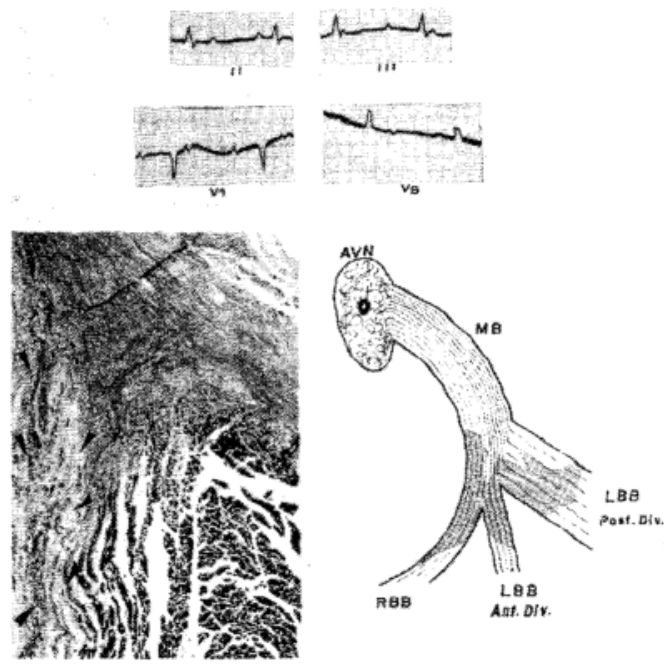

Figure 3 - Case no 3, 46 year old male. Lesions in this case present a configuration similar to those found in cases of Lenegre's disease. There is sclero-atrophy involving both bundle branches. Photo illustrates (arrow heads) atrophy of the right bundle branch. One can also see the central fibrous body of the heart and the septal myocardium. Hematoxylin and eosin, $80 \mathrm{X}$.
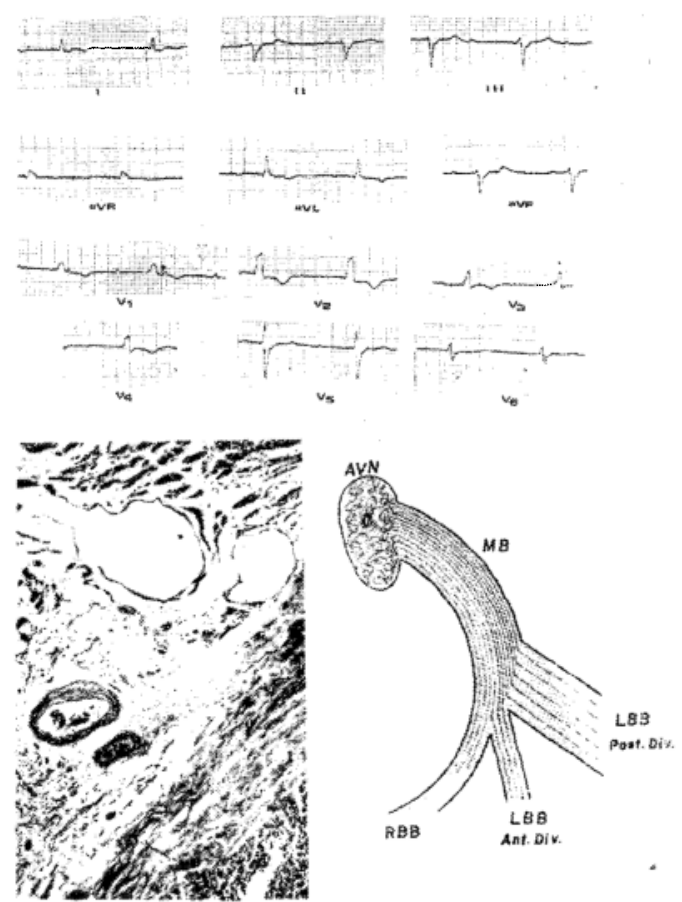

Figure 4-Case n.0 4, 66 year old female. The conducting tissue in this case appeared completely destroyed and replaced by a loose connective tissue with many thin-walled dilated blood vessels. These findings are well illustrated in the accompaning microphotography. Masson's trichrome $80 \mathrm{X}$.
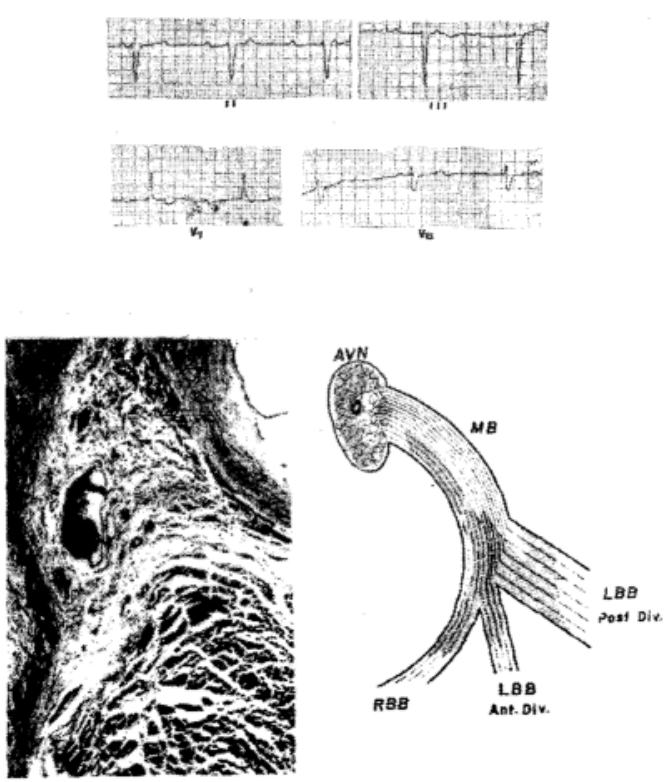

Figure 5-Case n. 5, 41 year old female. Lesions are marked at the lower end of the His bundle and at their bundle branches. The picture shows the His bundle with considerable degree of atrophy and vascular dilatation and congestion. At the left side, some preserved fibers can be noted. The lower part of the picture is represented by the septal myocardium. Masson's trichrome, $80 X$.

and right portion of the node, the presence of dense fibrosis was noted. Inflammatory changes were practically absent in all cases. The main nodal artery appeared thickened due to medial hypertrophy and sub-endothelial fibrosis. Some thin-walled telangiectactic vessels frequently appeared around the main artery.

His' main bundle: penetrating portion in Case No 1 showed atrophy and some degree of calcification, which appeared as an extension of the dense calcification present in the central fibrous body of the heart. The remaining cases had this penetrating portion more well preserved. In all cases, lesions of atrophy, fibrosis, vascular ectasis and mild inflammatory infiltration were present all along the bundle, but were more marked in its right-half. Foci of fatty infiltration were common at the most inferior portions, especially near the origin of the right bundle branch.

In Case No 2 the main bunble showed fibrosis along its left side, which involved the area of origin of the posterior fasciculi of the left bundle branch.

Bundle branches: these were the areas of the conducting tissue most involved in the present series, especially for the right bundle and the anterior portion of the left bundle branch, since at least 20 to $40 \%$ of the posterior fasciculi of the left branch maintained its nor- 
mal looking appearance. Sclero-atrophy was the most prominent lesion, but vascular ectasia and fibrosis were seen in two cases involving the right bundle branch.

Clinico-pathological correlations: there was good correlation between the electrocardiographic and anatomical findings. The most probable explanation for the ECG pattern of RBBB+LAH, with ventricular rates of about $40 \mathrm{bpm}$, is that the idio-ventricular command or escape was located near or within the posterior fasciculi of the left bundle branch: or even in the His' main bundle, just below the blocked zone, the electrical impulse being propaged along the posterior fasciculli of the left branch. As for the Case no 2, which presented the RBBB pattern, but with extreme deviation of the QRS axis to the left $\left(-150^{\circ}\right)$, it can be assumed that the idio-ventricular pace-maker could be distally located, but still within the posterior fasciculli of the left branch, which would be in agreement with the lower cardiac rate $(36 \mathrm{bpm})$ presented by the patient. In the sole case with LBBB and ventricular rate of $45 \mathrm{bpm}$, the idio-ventricular escape mechanism was probably located in the right bundle branch. Thus, during the course of chronic Chagas' myocarditis, even when complete atrioventricular block has ensued, there is a tendency for the persistence of the most usual ECG pattern: complete right bundle branch block, most of the times associated with left anterior hemiblock (RBBB+LAH).

\section{COMMENTS}

The conducting tissue of the heart is involved by inflammatory, degenerative, vascular and infiltrative changes during the course of chronic Chagas' myocarditis 1213 and to this anatomical involvement there correspond a florid electrocardiographic counterpart ${ }^{1}$. Therefore, it should not come as a surprise that an accentuation of such changes be found in cases showing complete atrioventricular block. However, the demonstration that disseminated lessions all along the conducting tissue, rather than a single, focal, interruptive lesion, were the cause of complete atrioventricular block, points out to matters of extraordinary conceptual importance.

Etiology and pathogenesis of chronic (permanent) acquired complete atrioventricular block is not generally determined. There are speculations that ischemic, degenerative or inflammatory factors may be responsible for this end-stage pathological presentation (see reviews by Davies ${ }^{5}$ and Rossi ${ }^{17}$ ). Consequently, it is of interest to know about the changes present in cases of complete atrioventricular block in Chagas' disease, an inflammatory condition of known etiology.

It has been generally assumed that the commonest pathological pattern of lesions responsible for chronic atrioventricular block is destruction of both bundle branches 561013 . Similar destruction was seen in the branches in the present cases studied, which seems to confirm the extreme vulnerability of these structures. However, such vulnerability does not seem to apply to the posterior fasciculli of the left bundle, the least involved part of the conducting system in Chagas' myocarditis. Only in one case (Case No 3) there was an apparently isolated and concentrated lesion at the distal parts of both bundle branches. This happened to a 46 year old male patient who first presented complete left bundle branch block, an unusual manifestation of Chagas' myocarditis ${ }^{15}$ and evolved some years later to 2nd degree atrioventricular block and finally presented with complete A-V block (see Table 1). Whether

Table 3 - General clinico-pathological data on 5 cases of chronic Chagas' myocarditis and complete atrioventricular block

\begin{tabular}{cccccc}
\hline Case & $\begin{array}{c}\text { Age } \\
\text { (years) }\end{array}$ & Sex & $\begin{array}{c}\text { Heart weight } \\
(g)\end{array}$ & Myocarditis & Fibrosis \\
\hline 1 & 74 & M & 800 & $*$ & $* *$ \\
2 & 32 & M & 550 & $* * *$ & $* *$ \\
3 & 46 & M & 450 & $* * *$ & $* * *$ \\
4 & 66 & F & 500 & $* * *$ & $* *$ \\
5 & 41 & F & 450 & $* * *$ & \\
\hline
\end{tabular}

\footnotetext{
$=$ mild

$* *$ = moderate

$* * *=$ severe

Grandes refer to changes in the ordinary myocardium, not in its conducting tissue.
} 
sclero-atrophy of both bundle branches (Lénegre's disease) can be caused by chronic myocarditis, or whether the lesion found in Case no 3 is unrelated to myocarditis is impossible to be established at the moment.

Davies $^{5}$ has stated that in Chagas' disease, bundle branch fibrosis is undoubtedly caused by a chronic myocardits, and concluded that "it is such facts that have led to the supposition that idiopathic bundle branch fibrosis is caused by previous sub-clinical or unrecognized attacks of acute myocarditis".

It has been emphasized that there are two common causes of chronic A-V block: idiopathic bundle branch fibrosis (Lenegre's disease) and fibrocalcific destruction of the conduction system due to primary changes in the fibrous skeleton of the heart (Lev's disease). Only one case of the present series had some resemblance to this latter. Case n. 1 , representing a 74 year old male, who had a three-year duration complete A-V block, and arterial hypertension, showed calcification of the central fibrous body and considerable atrophy of the penetrating portion of the His' bundle. Probably the calcifying change was related to old age or to ischemic insult, as reported by Lev11. However, the lesion at the initial portion of the His' bundle did not cause rupture of the conducting fibers, and there were other more conspicous lesions in other parts of the system, apparently unrelated to the fibrocalcific alterations. This case can not be diagnosed as Lev's disease, although some early component of the latter may have been represented.

Pathological studies made in Japan 718 in cases of complete atrioventricular block, have revealed lesions very similar to those here described for Chagas' disease. The Japanese authors seem convinced that atrioventricular block manifests itself as the result not of any localized damage but of a totality of focal lesions involving the entire conduction system.

The analysis of the changes found in the present series suggests a dynamic pathogenetic process that can lead to complete destruction of the conducting system. The strategic location of the lesions appears as an important issue, since at least two of the present cases showed a pattern similar the one that has been described for cases of Chagas' disease associated with right bundle branch block and left anterior hemiblock ${ }^{12}$.

Although the atrioventricular node appeared severely damaged, that structure was nevertheless seen to be much less involved than the rest of the conducting system. The finding of an A-V block with a narrow QRS is rare in Chagas' disease and the absolute majority of total cardiac block have been demonstrated to be of a post-Hissian type ${ }^{12}$, which is in keeping with the findings of the present study.

\section{RESUMO}

O estudo do sistema de condução atrioventricular através cortes seriados completos em cinco casos humanos de miocardite crônica chagásica e bloqueio A-V total revelou a presença de lesões de esclero-atrofia, fibrose, ectasia vascular, fleboesclerose e inflamação crônica inespecífica envolvendo o sistema de maneira disseminada, mas com distribuição e intensidade variaveis de caso para caso. Em um caso, todo o sistema, do nódulo $A-V$ até as porções distais dos ramos, apareceu destruido. Em três casos havia lesões disseminadas, mas as mesmas não causavam solução de continuidade completa do sistema. O setor mais lesado esteve representado pelos ramos direito e a divisão anterior do ramo esquerdo do feixe de His, mas os fascículos da divisão posterior do ramo esquerdo estavam em boa parte preservados. Um caso exibia esclero-atrofia localizada nas porçōes distais de ambos os ramos. Em uma oportunidade, a calcificação acentuada do esqueleto fibroso da base do coração estendia-se e envolvia ligeiramente a porção penetrante do feixe de His, não causando, todavia, a sua rotura. $O$ nódulo $A-V$, embora com graus variáveis de esclero-atrofia e fibrose, apareceu como o setor menos lesado nesta série de casos.

$A$ demonstração das lesões nestes casos de bloqueio A-V total parece importante porque: a) revela que as lesões que causam tal bloqueio na doença de Chagas são variáveis e disseminadas, ao contrário do que se vê em casos de outras etiologias, onde as lesões são focais; b) mostra que um processo inflamatório crônico pode dar origem no final a complexas lesões vasculares, degenerativas e fibróticas no tecido de condução, podendo levar à completa destruição desse sistema, o que pode ser importante para a interpretação de casos semelhantes, hoje tidos como idiopáticos.

Palavras chaves: Miocardite chagásica crônica. Bloqueio atrioventricular.

\section{REFERENCES}

1. Andrade ZA. Bases morfológica das arritmias na miocardite chagásica. In: Cançado JR, Chuster M (ed). Cardiopatia chagásica. Fundação Carlos Chagas, Belo Horizonte, 1985.

2. Andrade ZA, Andrade SG, Oliveira JB, Alonso DR. Histopathology of the conducting tissue of the heart in Chagas'myocarditis. American Heart Journal 93:316-324, 1978.

3. Chagas C. Nova entidade mórbida do homem. Memórias do Instituto Oswaldo Cruz 3:220-275, 1911.

4. Chagas C, Villela E. Forma cardiaca da Trypanosomiase Americana. Memórias do Instituto Oswaldo Cruz 14: 5-61, 1922 . 
5. Davies MJ. Pathology of the conducting tissue of the heart. Butterworth \& Co, London, 1971.

6. Davies MJ, Harris A. Pathological basis of primary heart block. British Heart Journal 31:219-226, 1969.

7. Fukuda K. Histopathological study on the conduction system with complete atrioventricular block. With special reference to configuration of QRS complex. Japanese Circulation Journal 42:1265-1278, 1978.

8. Ginefra P. Dias JCP, Camacho LAB, Oigman W, Laranja FS. História natural do bloqueio atrioventricular do terceiro grau da miocardiopatia chagásica crônica. Arquivos Brasileiros de Cardiologia 41:441-447, 1983.

9. Guimarães AC. Aspectos eletrocardiográficos da cardiopatia crônica. In: Cançado JR, Chuster M (ed). Cardipatia Chagásica. Fundação Carlos Chagas, Belo Horizonte, 1985.

10. Lénègre J. Etiology and pathology of bilateral bundle branch block in relation to complete heart block. Progress in Cardiovascular Diseases 6:409-444, 1964.

11. Lev M. Anatomical basis for atrioventricular block. American Journal of Medicine 37:742-748, 1964.

12. Lorga AM, Garzon SAC. Bloqueio atrioventricular na cardiopatia chagásica crônica: evolução e localização pelo eletrograma do feixe de His. In: Dohmann HJF, Ro- cha AFG (ed.) Conceitos atuais em cardiopatia. Editora Guanabara, Koogan, Rio de Janeiro, 1978.

13. Oliveira JAM, Oliveira JSM, Köberle F. Pathologic anatomy of the His-Tawara system and electrocardiographic abnormalities in chronic Chagas'heart disease. Arquivos Brasileiros de Cardiologia 25:17-25, 1972.

14. Pickett $P$, Sommer JR. Thirty-five mm film as mounting base and plastic spray as cover glass for histologic sections. Archives of Pathology 69:239-247, 1960.

15. Pinto-Lima FX, Spiritus O, Tranchesi J. Arrhythmias and vector electrocardiographic analysis of complete bundle branch block in Chagas'disease. A study of 103 autopsy cases. American Heart Journal 56:501-509, 1958.

16. Rassi A, Carneiro O. Estudo clínico, eletrocardiográfico e radiológico da cardiopatia chagásica crônica. Análise de 106 casos. Revista Goiana de Medicina 2:287-296, 1956.

17. Rossi L. Histopathology of cardiac arrytmias, 2a Edition Casa Ambrosiana, Milan, 1979.

18. Takagi T. Pathological studies on atrioventricular conduction disturbances. Acta Pathologica Japonica 28:815$842,1978$. 